\title{
Hydraulics and Hydrology in a Passage of the Kitāb al-Ātār al-Bāqiya by al-Bīrūn̄̄
}

\author{
A PREPRint Version. PAPER ACCEPTED in MAy 2020 FOR PUblication IN \\ Arabic Sciences and Philosophy, vOL. 31 Issue (2) SEPTEMBER 2021
}

\author{
Massimiliano Borroni \\ Dipartimento di Studi sull'Asia \\ e sull'Africa Mediterranea \\ Università Ca' Foscari \\ Venezia, IT 30123 \\ massimiliano.borroni [at] unive(dót) it
}

\author{
Vladimiro Boselli \\ Dipartimento di Ingegneria Civile Ambiente \\ Territorio Architettura e Matematica \\ Università degli Studi di Brescia \\ Brescia, IT 25123 \\ v.boselli[at]unibs (dot)it
}

November 25, 2020

\begin{abstract}
The authors translate and comment a digression from the Kitāb al-Ātār al-Bāqiya on several hydraulic and hydrological subjects. The passage reveals al-Bīrūnī's understanding of fluvial regimes, water physical behaviour, and of a handful of peculiar natural phenomena. Al-Bīrūnī departs from a discussion of weather forecast and seasonal fluvial regimes of the Tigris, Euphrates, Oxus, and Nile. The main concern of al-Bīrūnī is to defend the principle that water moves only downwards in absence of external forces. In doing so, the Khwarazmian scientist touches on the origin of salinity of the seas, the functioning of syphons related hydraulic machines, and relates a report of an artificial phenomenon, that he dismisses as result of faulty observations, that could be recognized as a hydraulic jump. In addition, the passage contains much relevant information on al-Bīrūn̄̄s understanding of the inhabitability of subequatorial regions, the possibility of the void, and the water cycle.
\end{abstract}

\section{Introduction}

In the present article ${ }^{1}$ we discuss a passage from the Kitāb al-Ātār al-Bāqiya, the well-known first written work of Abū Rayhān al-Bīrūnī (362/973 - 440/1048 or 442/1050). ${ }^{2}$ We rely on philological and hydrological notions to provide an improved translation ${ }^{3}$ and commentary. In this passage, the Khwarazmian polymath digresses from the main subject

1 Massimiliano Borroni wrote the cultural and historical contextualization, linguistic analysis, and translation, and carried out the final write-up. Vladimiro Boselli wrote the scientific and engineering discussions, the epistemological contextualization and provided the images in this article. The authors worked together on textual analysis.

2 The details of al-Bīrūn̄'s life under the Ghaznavids are not entirely clear, and so it is the date of his death. Boilot holds that he died after 442/1050, because al-Bīrūnī states in his last important work, the Kitāb alSaydala $f i$ al-tibb, that he was over 80 years old. Bosworth, following Karimov and Bulgakov, disagree and places the date of death at 440/1048. D.J. Boilot, 'Al-Bīrūn̄̄', in Encyclopædia of Islam, Second Edition, 2012, http://dx.doi.org/10.1163/1573-3912_islam_SIM_1438; Clifford Edmund Bosworth, 'Bīrūnī, Abū Rayhān I. Life', in Encyclopædia Iranica, 2010, http://www.iranicaonline .org/articles/biruni-abu-rayhan-i-life.

3 There is, indeed, a well-known English translation of the Kitāb al-Ātār al-Bāqiya by Sachau. We felt that this passage needed an updated translation because of its technical content. Since Sachau's interest for the $\bar{A} \underline{\underline{a}} r$ was dictated mainly by philological, chronological, and historiographical reasons, his translation of this more technical - and at times slightly obscure - passage suffers from some rare inaccuracies and is at times not as clear as it could have been. 
matter of the $\bar{A} t \bar{a} r$, i.e. calendars and chronology, to discuss a wide range of topics regarding water. In broad terms, the text deals with subjects in the field of hydrology and environmental hydraulics. ${ }^{4}$ The entire passage is dictated by the urgency to state a general principle governing the behavior of water, and the technical limitations that said principle imposes on engineering enterprises, a chief interest of al-Bīrūnī, who saw science as a 'problem solving activity'. ${ }^{5}$ The central statement that al-Bīrūnī puts forth in this passage is that water cannot rise above its point of origin. We will spend a few words on the context of this passage, before discussing the theses put forward by al-Bīrūnī and their relevance for our understanding of his methods.

\section{Context of the Digression}

Abū Rayhān al-Bīrūn̄̄, native of the suburbs of Kāt, which was then capital of Afrighid Khwarezm, is as well-known today as he was in his time for the variety of his learning and his empiricist approach. The subject of empiricism is ubiquitous in scholarly literature on any aspect of al-Bīrūnī work and life, and it even made its way into more popular literature, as the case of a UNESCO anthology dedicated to al-Bīrūnī testifies. ${ }^{6}$ The passage discussed in this paper enlightens us on the nature of al-Bīrūnī's empiricism, which can be better understood in the context of the general agreement between rational inquiry and Islamic revelation recognized by Bausani as the hallmark of Bīrūnī's thought. ${ }^{7}$ At the same time, this short text gives us a few clues to his understanding of climatic, hydrological and hydraulic phenomena at the time of the composition of the Ātār. In 338/998 al-Bīrūnī left the court of his first patron, the Samanid ruler Manșūr, relocating in Jurjān at the dependence of the Ziyarid Sultạn Qabūs. ${ }^{8}$ In 390/1000 al-Bīūn̄ī dedicated the $\bar{A}$ tāar (also known under the english title The Chronology of the Ancient Nations) to him. Kitab al-Ātār al-Bāqiya 'an al-Qurūn al-Häliya, which is a treatise on chronology, discusses the calendars and festivals of several peoples known to the author. ${ }^{9}$ In doing so, it touches both calendrical history and the astronomical aspects of time reckoning - al-Bīrūnī discusses, for instance, the calendrical reform of the Khwarazmshāh of mid-tenth century ${ }^{10}$ and devotes the last pages of

4 Hydrology is that branch of science studying the movement, distribution and quality of water throughout the Earth including the hydrological cycle. Hydraulics is a branch of mechanics, continuum mechanics to be more precise, dealing with the mechanical properties of liquids, its topics applied to engineering problems to study pipe flow, reservoir design, pumps and channel behaviour. For a discussion of hydrology, hydraulics and broadly speaking scientific knowledge pertaining to water in the Arabo-Islamic tradition see Mohammed El-Faïz, Les Maitres de l'eau: Histoire de l'hydraulique Arabe (Arles: Actes Sud, 2005), 94-100. For a discussion on the evidence for transmission of classical water technology to the early Islamic world see A. I. Wilson, 'Classical Water Technology in the Early Islamic World', in Technology, Ideology, Water: From Frontinus to the Renaissance and beyond: Papers from a Conference at the Institutum Romanum Finlandia, May 19-20, 2000, ed. Ari Saastamoinen and Christer Bruun, vol. Acta Instituti Romani Finlandiæ (Rome: Institutum Romanum Finlandiæ, 2003), 115-41. On mechanical and civil engineering - both closely connected to water management - in the pre-modern Islamic civilization see the relevant chapters in Ahmad Y. al-Hassan and Donald R. Hill, Islamic Technology: An Illustrated History (Cambridge; Paris: Cambridge University Press; UNESCO, 1986), 37-91.

5 A. L. Samian, "Virtues in Al-Biruni's Philosophy of Science", in Timing and Temporality in Islamic Philosophy and Phenomenology of Life, ed. Anna-Teresa Tymieniecka, Islamic Philosophy and Occidental Phenomenology in Dialogue 3 (Dordrecht: Springer, 2007), 268-69.

6 Vv. Aa., 'Al-Biruni: Miniature Anthology, Including Many Translated into English for the First Time', The UNESCO Courier: A Window Open on the World, 1974.

7 Bausani stressed that "for Bīrūn̄̄ science and the Qur'ān agree, esoteric ma 'rifa and the Qur'ān do not”. Alessandro Bausani, 'Bīrūnī between "Scientia" and "Sapientia". Some Remarks on Bīrūn̄̄s "Modernity"', in Mélanges d'islamologie: Volume Dédié à La Mémoire de Armand Abel, ed. Pierre Salmon (Brill, 1974), 63.

8 Qābūs b. Wušmgīr, Ziyarid ruler of Jilan between the tenth and eleventh century also known by his laqab Šams al-Ma ālī (Sun of Eminences), was both a patron of the sciences and an astronomer himself. His interest in astronomical and calendrical matters is well represented by the tower he built in Ǧurğān, today Gonbad-e Kavūs) as a time-measuring monument. Simone Cristoforetti, 'Cycles and Circumferences - The Tower of Gonbad-e Kāvus as a Time-Measuring Monument', in Borders: Itineraries on the Edges of Iran, ed. Stefano Pellò, Eurasiatica Quaderni Di Studi Su Balcani, Anatolia, Iran, Caucaso e Asia Centrale (Venezia: Edizioni Ca' Foscari, 2016), 89-115; http://doi .org/10.14277/6969-100-3/EUR-5-5.

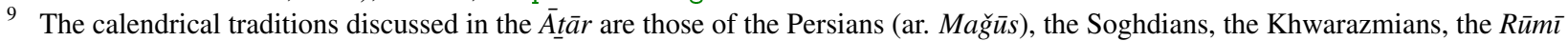
(i.e. the Byzantines), the Jews, the Melikite and Nestorian Christians and, with regards to Lent, Christian sects in general, the Sabians (of Harrān), the pre-Islamic Arabs, and, of course, the Muslims.

${ }^{10}$ On this reform that set the spring equinox as the date of the Iranian New-Year's day, see Simone Cristoforetti, 'Nowruz III. in the Iranian Calendar', in Encyclopædia Iranica, online edition, 2009, http://www.iranicaonline.org/articles/nowruz-iii. 
the Ātār to the subject of lunar stations (Ar. manāzil al-qamar). ${ }^{11}$ The chapter that interests us deals with the calendar of the Rūmī, i.e. the Byzantines, listing the days of their calendars. Here, al-Bīrūnī provides the reader with the anw $\bar{a}^{2}$ for each day of the year. $A n w \bar{a}^{\prime}$ (singular $n a w^{\prime}$ ) are an astronomical tool for weather prediction that the scientists of the Islamic period most commonly based on a combination of pre-Islamic Arab and Indian astronomical techniques to predict the weather of a given year. ${ }^{12}$ As such, $a n w \bar{a}^{3}$ literature tends to be based on a lunar calendrical system. For the purpose of weather forecasting, though, al-Bīrūnī seems to favor a solar one: the Rēmin, i.e. Julian, calendar.

\section{Climatology and Weather Forecast}

The passage we intend to discuss here stems from a succinct statement on the anw $\bar{a}^{\supset}$ for the 28th day of Nīsān, or April [ף1]. Al-Bīrūnī cites two sources for this day: Eudoxus of Cnidos (ca. 408-355 B.C.) and Abū Sa '̄ìd Sīnān b. Tāäbit b. Qurra (880-943). The source for the anw $\bar{a}^{2}$ of Eudoxus may be an Arabic translation of his Ceimonos Prognostica, a treatise on bad-weather predictions of Babylonian origin. According to Frisinger, Eudoxus was "the last natural philosopher in the pre-Aristotelian tradition to have taken an interest in meteorolog" and, according to Pliny, held "an interesting theory on the periodicity in weather phenomena." ${ }^{13}$ Both Eudoxus and Sīnān are discussed in the opening of the chapter on the Rūmi calendar in a brief preamble. ${ }^{14}$ Al-Bīrūnī distinguishes between two schools of thought on the $a n w \bar{a}$ : those who base their $a n w \bar{a}^{3}$ on the study of the fixed stars and the relative lunar stations - as we noted above - and those who rely on the days of the solar calendar. Among the latter, al-Bīrūnī counts Sinnān ${ }^{15}$ and says that his $a n w \bar{a}^{\prime}$ were based on the empirical observations conducted by Sinnān's father, the celebrated Sabean scientist and mathematician Tāābit b. Qurra (21 CE/826 h. - 288 CE/901 h.), over the course of thirty years in Iraq. Al-Bīrūnī points out that the correctness of the anwă $\bar{a}^{\prime}$ given by the handful of authorities he refers to in the R $\bar{u} m \bar{\imath}$ calendar chapter are subject to several conditions, such as the character of the year, the region where they were developed, and so on. In other words, al-Bīrūnī conceives these $a n w \bar{a}^{\supset}$ more like a climatology based on a heuristic than meteorology:

The correctness of the $a n w \bar{a}^{3}$ depends [on certain conditions]. For instance, to foresee the character of the year, the season, the month, whether it will be dry or moist, whether it will answer to the expectations of 40 people or not, to prognosticate it by means of the signs and proofs, of which the astronomical books on meteorology are full. For if the $a n w \bar{a}^{3}$ agree with those signs and proofs, they are true and will be fulfilled in their entire extent; if they do not agree, something different will occur. ${ }^{16}$

11 The relevance of the lunar stations, i.e. the segments of the ecliptic through which the Moon passes in its orbit, serves the astronomical interests of al-Bīrūnī and Șultān Qābūs the author seems to hold some scepticism over the relation between Lunar stations and meteorological events. Abū Rayhān Muhammad Al-Bīrūn̄̄, Al-Ātāar al-Bāqiya 'an Qurūn al-Hāaliya, ed. Eduard Sachau (Leipzig: Otto Harassowitz, 1923), 338-39.

12 Daniel Martin Varisco, 'The Origin of the Anwà' in Arab Tradition', Studia Islamica, no. 74 (1991): 5-28, https://doi.org/10.2307/1595894; Daniel M. Varisco, "Anwā’", in Encyclopcedia of Islam, THREE, ed. Kate Fleet et al., 1 Nov. 2007, https://referenceworks .brillonline.com/entries/encyclopaedia-of-islam-3/anwa-SIM_0222; Charles Pellat, 'Dictons Rimés, Anwā' et Mansions Lunaires Chez Les Arabes', Arabica 2, no. 1 (1955): 17-41; Fuat Sezgin, Geschichte Des Arabischen Schrifttums, vol. 7 (Leiden: Brill, 1979), 339-70.

${ }^{13}$ H. Howard Frisinger, The History of Meteorology: To 1800 (Boston: American Meteorological Society, 1983), 10, 15; George Sarton, A History of Science: Ancient Science through the Golden Age of Greece (Cambridge: Harvard University Press, 1960), 447.

${ }^{14}$ Al-Bīrūn̄i, Ātār, $242-43$.

15 Al-Bīrūnī is referring to a treatise on the anwā' composed by Sīnān for the Abbasid Caliph Al-Mu'tadid. This treatise is probably his main source for the weather recording carried out by Tābit b. Qurra. It is noteworthy that astronomers coming from a Sabian background such as the Banū Qurra would prefer a solar and rather empiricist approach to weather forecasting, despite their fame for astrolatry. The ample citations provided by al-Bīrūnī are all that remains of Sīnān's treatise on the anwä', which seems to have been largely based on the Phaseis of Ptolemy. See Julio Samsó and J. Blas Rodríguez, 'Las "pháseis" de Ptolomeo y el "Kitāb al-Anwā" de Sinān b. Tābit', Al-Andalus 41 (1976): 15-48. For a discussion on the impact of Aristotle's Meteorologica see Paul Lettinck, Aristotle's Meteorology and Its Reception in the Arab World, with an Edition and Translation of Ibn Suwār's Treatise on Meteorological Phenomena and of Ibn Bäjja's Commentary on the Meteorology (Leiden: Brill, 1999).

${ }^{16}$ Al-Bīrūn̄i, Ātār, 243. 
A Preprint - November 25, 2020. Accepted in Arabic Sciences and Philosophy Vol. 31(2) SePt. 2021

\section{The River Regimes}

Both of Eudoxus and Sinnān agree that on this day there is a tendency towards rainfall, and that rivers grow in this period. Al-Bīrūnī departs from this statement to elaborate on the physical link between these two phenomena: rainfall and river regimes, and it should be noted that al-Bīrūn̄i, in agreement with Sīnān, stresses the importance of regional peculiarities when dealing with $a n w \bar{a}$. It is a principle that applies well to the case of rivers regimes and the hydrological record pertaining to the different regimes of the great rivers of the dār al-Isläm prompts this thematic diversion that moves from hydrology to hydraulics, and closes with a few stray observations on counterintuitive phenomena, that captured al-Bīrūnī’s intellectual curiosity. In the first paragraph [đ1], al-Bīrūnī mentions the rising of both rivers and awdiya (pl. of $w \bar{a} d \bar{l}$, lit. valley). According to his sources, the 28th of April is the day that usually marks the begin of water streams' growth, but he is quick to point out that each river presents its own peculiarities. In modern hydrology, the term wadi is used to indicate typical streams in arid regions which presents occasional waterflows for very short periods of time. Here al-Bīrūnī clearly understands the term more broadly, referring to any stream of moderate proportion that eventually feeds into larger rivers, notwithstanding the arid character of the region where it flows. Therefore, in our translation we have kept with Sachau's rendition of $w \bar{a} d \bar{l}$ as streams. First, Al-Bīrūnī states that rivers and wadis may present different regimes. Then, he discusses the cases of the four great rivers of the antiquity: Oxus (or Amu Darya), Tigris, Euphrates, and Nile. He notices that the Oxus has a higher flow in summer because of the snowmelt. This is what is nowadays called a nivo-glacial regime, whilst Tigris and Euphrates show an increase in their flow when the season is rainy because precipitation plumps the rivers directly flowing in them, or, in today’s terms, a pluvial regime [ $\mid 2-\llbracket 3]$. The term originary waters (Ar. miyāh așliyya, sing. $m a^{2}$ așlì) should not be overlooked. Al-Karājī employs the same

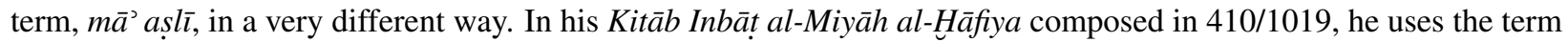
for the ground water generated in the depth of the Earth from air, adhering to the Aristotelian model of the endogenous cycle. ${ }^{17}$ Instead, al-Bīrūnī implicitly disregards the Aristotelian endogenous cycle in favour of an exogenous one. ${ }^{18}$ His view on this subject falls squarely in the paradigme babylonien of the water cycle that have its oldest extant example in the Kitāb al-Filäha al-Nabatiyya. ${ }^{19}$ This implicit assumption reveals itself again and again in the following pages. In fact, it provides the foundations for al-Bīrūnì's understanding of the natural cycle of water. Another term that merits a brief discussion is $w u q \bar{u} \bar{u}^{`}$ al-andiyya. Sachau translates it literally as dewfall. Nevertheless, it is apparent to us that al-Bīrūnī is not referring exclusively or even primarily to droplets of water due to condensation. He has in mind the more general phenomenon on precipitation, including rain and snow, as he refers to the latter a few lines later. In this paper, we will always refer to $a n d \bar{a}^{2}$ (pl. andiyya) as a general term for natural occurring water from precipitation. A third element of interest emerging from this paragraph pertains to the geography of the rivers Tigris and Euphrates, on the one side, and the Oxus, on the other. Al-Bīrūnī is confident that the discrepancy between the two fluvial regimes can

${ }^{17}$ Mehdi Nadji and Rudolf Voigt, "'Exploration for Hidden Water" by Mohammad Karaji-The Oldest Textbook on Hydrology?', Groundwater 10, no. 5 (1972): 44, https://doi.org/10.1111/j.1745-6584.1972.tb03592.x; Muhammad al-Karājī, Inbāt Al-Miyah al-Hāfiya, ed. Baghdad 'Abd al-Mun'im (Baghdad; Cairo: Ma'had al-Mahtūtāt al-'Arabiyya, 1997). On alKarājī's debt towards the Aristotelian model see Kaveh Niazi, 'Karajī's Discourse on Hydrology', Oriens 44, no. 1/2 (2016): 44-68.

18 Antiquity knew three main theories on the origin of water springs. Two of them are endogenous, and one exogenous. The oldest, and most correct, one is the exogenous theory exposed by Anaxagoras. According to Anaxagoras, water springs are fed by rainwater that infiltrated the soil. It seems clear to us that al-Bīrūnī is relying on a similar understanding of the water cycle. A second, endogenous, theory is that of Plato. He believed that the water flowing from springs derived from reservoirs on the mountains, either fed by sea water, or generated in the depth of the earth. The third theory, exposed by Seneca and Aristotle, entailed that water was generated inside underground cavities. Aristotle held that this water was generated by condensation of vapor, in analogy to the condensation of water vapor in the sky. Instead, Seneca believed that this generation took place by transmutation of terrestrial and aerial humors. James C. I. Dooge, 'Background to Modern Hydrology', in The Basis of Civilization - Water Sciemce? (Proceedings of the UNESCO/IAHS/IWIIA Symposium Held in Rome. December 2003), ed. John C. Rodda and Lucio Ubertini, IAHS Series of Proceeding and Reports 286 (Wallingford: IAHS Press, Centre for Ecology and Hydrology, 2004), 3-12; Franco Ravelli, 'Il ciclo idrologico naturale nel pensiero dei classici fino agli albori della moderna idrologia', Rivista di storia dell'agricoltura 40, no. 1 (2000): 3-32.

19 El-Faïz, Les Maitres de l'eau: Histoire de l'hydraulique Arabe, 87; Abū Bakr Aḥmad b. 'Alī b. Qays al-Kasdānī, Al-Filāhah al-Nabatīyah. Al-Tarğama al-Manhūla Ilā Ibn Wahshīya, ed. Fahd Toufic, 3rd ed. (Damascus: Insititut Français de Damas, 1993-8). 
be explained on a geographical basis, which is of course true since, but not in the terms he puts forward. According to al-Bīrūnī, the reason for this difference between fluvial regimes lies in the fact that the sources of the Oxus are much further north than those of the Mesopotamian rivers. Now, al-Bīrūnī adhered to the school of thought that believed that regions found at the same latitude enjoyed substantially the same climate and opposed the Indo-Persian geographical tradition that divided the world in circular regions called kishwar centred around İrānshahr. ${ }^{20}$ In light of this, it is clear why this seemed to him the only reasonable explanation for the phenomenon, leading him to overlook the fact that the sources of the three rivers are approximately at the same latitude. To be fair, his reasoning is not entirely mistaken. The sources of the Oxus are in fact frozen when the Tigris and the Euphrates receive rainfall, but this is due to the fact that the Oxus springs from mountains that are considerably higher and further removed from any nearby sea. It is not clear whether - at least at this point in his life - al-Bīrūnī was mistaken on the geography of the Mesopotamian rivers, on the Oxus, or both. ${ }^{21}$

\section{The Nile's Sources}

The argument becomes more complex as the author takes into consideration the case of the Nile [ 94 ]. The fact that the Nile floods in summer would seem to contradict his previous statement on rivers that do not have their sources in the far north. In other words, why do the flows of Tigris and the Euphrates peak during the rainiest season, while the Nile floods during the dry one? To answer this question Al-Bīrūnī puts forward two twin hypotheses, both resting on an increase in precipitation at the whereabouts of the (unknown) Nile's sources. The first hypothesis is that the sources of the Nile may be water springs located south of the equator, where solar seasons would be reversed. For this reason, argues al-Bīrūnī, the mountain reservoirs feeding those springs would have a rainy cold season in those months when the regions north of the Equator enjoy warm weather. Al-Bīrūnī writes that the sub-equatorial springs of

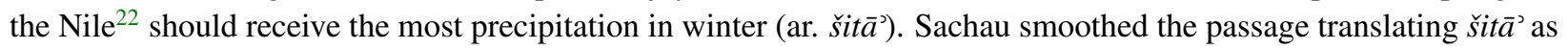
spring, probably on the ground that al-Bīrūnī mentions these $\check{s}_{i t} \bar{a}^{3}$ precipitations as a possible cause for the growth of the Nile in summer, ${ }^{23}$ but a closer translation here would be winter, since it is quite evident that al-Bīrūnī is referring to a sub-equatorial winter, or cold season, that would occur at the same time of summer in the northern hemisphere. The second hypothesis is that the great Egyptian river gets its water from streamlets located north or at the equator, that may get more water in summer from regional rainfall. Here, even though he does not say it out loud, al-Bīrūnī seems to think of a similar climatic situation as the rainy summers of Yemen he describes in another short digression on regional climatic discrepancies. ${ }^{24}$

\section{The Water Cycle and the Salinity of the Sea}

We find here a further implicit confirmation that al-Bīrūn̄ saw precipitations as the only source of water for the natural mechanism that feeds rivers. Even more, this assumption holds true no matter the geographical location or seasonal regime of a river. In the case of the Nile, al-Bīrūni admits that its seasonal behaviour cannot be fully explained, since he lacks empirical data on the sources of Nile, ${ }^{25}$ but even this lack of direct observations does not shake his bedrock

${ }^{20}$ Zayde Antrim, Routes and Realms: The Power of Place in the Early Islamic World (New York: Oxford University Press, 2012), 90-91.

${ }^{21}$ A future research may wish to investigate how al-Bīrūnī, whose competence as a geographer would not be under question, understood the hydro-fluvial basins of the known world.

${ }^{22}$ See Figure 1.

23 Abū Rayhạān Muḥammad Al-Bīrūn̄̄, The Chronology of Ancient Nations: An English Version of the Arabic Text of the Athar-UlBâkiya of Albîrûnî. or 'Vestiges of the Past', trans. C. Edward Sachau (London: W. H. Allen \& Co., 1879), 252.

${ }^{24}$ Al-Bīrūn̄i, Ātār, $245-46$.

${ }^{25}$ Here al-Bīrūnī sides with Ibn Sīnā and Ibn Rušd against Aristotle on the habitability of the southern hemisphere. See François De Blois, 'Aristotle and Avicenna on the Habitability of the Southern Hemisphere', in Studying the Near and Middle East at the Institute for Advanced Study, Princeton, 1935-2018, ed. Sabine Schmidtke (Piscataway N.J.: Georgias Press, 2018), 188-93. 


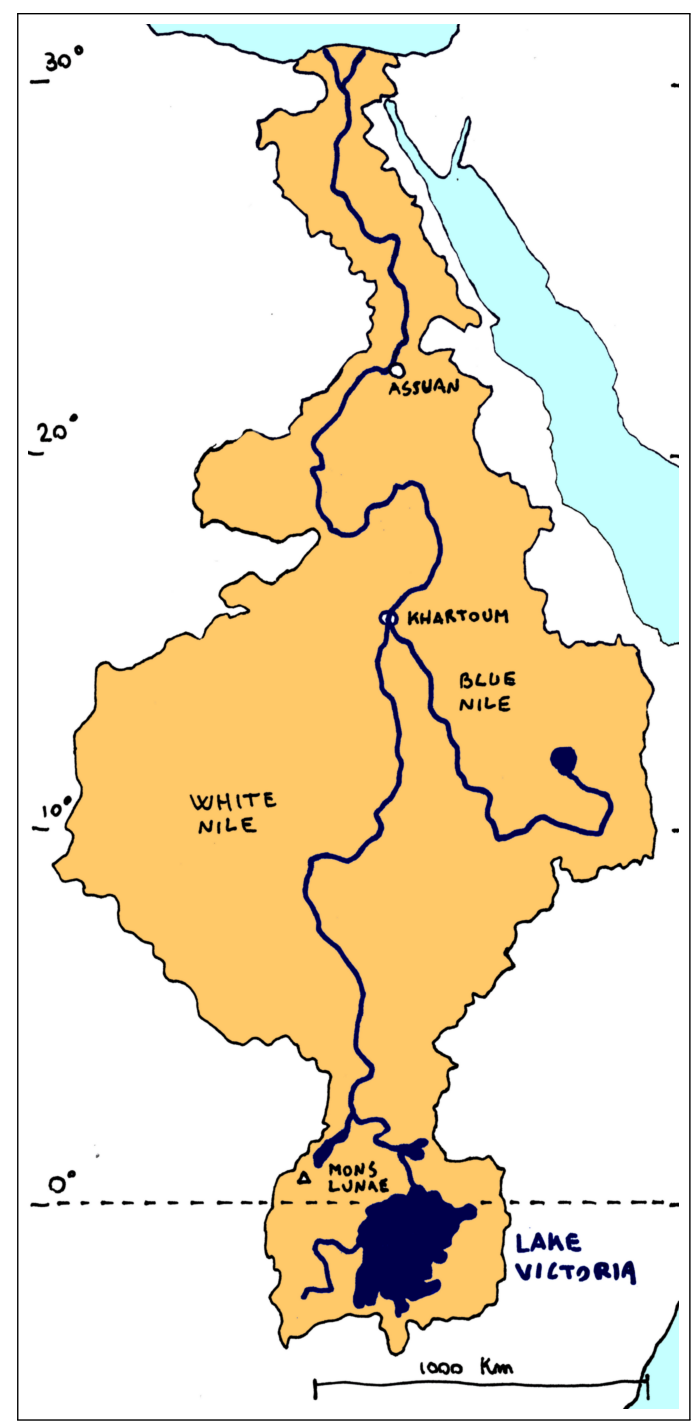

Figure 1: The Nile and its Sources

belief that whatever the environmental conditions may be at the sources of the Nile, we should assume that its water ultimately comes from water precipitation. In sum, al-Bīrūnī describes three different fluvial regimes relying on an exogenous model of the water cycle. The same understanding of the origin of running waters underlies his discussion of the seasonal regimes of water springs. This part of the digression [ $₫ 5]$ rests on the assumption that, in accordance with the divine design, mountain regions are the main recipient of water precipitation. Al-Bīrūnī makes here a quick reference to a book by Tāābit b. Qurra on the "why the mountains were created" (ar. Fī Sabab allad̄i lahu Huliqat $a l-G \breve{G} i b \bar{a} l$ ) and summarizes his opinion on the matter with a few words. This treatise appears to be lost, but a substantial summary by Miskawayh (d. 1030) is preserved in the Kitāb al-Hawāmil wa al-Shawāmil. ${ }^{26}$ Ibn Qurra's argument, such as it is related by al-Bīrūn̄̄ ${ }^{27}$ is teleological: the role of mountains as the main recipients of water precipitation

${ }^{26}$ Abū Hayyān al-Tawhidī wa Miskawayh, lemphKitāb al-Hawāmil wa al-Shawāmil, eds. A. Amīn and S. Saqr (Cairo: 1951), 354-6.

27 The intellectual kinship between al-Bīrūnī and Ibn Qurra is not limited to this subject. For instance, both mathematicians worked on the solar equation, that is the difference between the Sun's mean position on its ecliptic and its actual position. A possible link between al-Bīrūnī and the Harranian scholar could be envisaged in al-Buzjān̄̄, who collaborated from Baghdad with al-Bīrūnī and had been the teacher of al-Bīrūn̄̄'s teacher Abū Nașr Manșūr b. 'Alī b. 'Irāq. Michael Fedorov, 'The Khwarazmahahs of 
is to give salinity to the water that will eventually reach the sea. Miskawayh summary goes further, stating that the presence of mountains, that do not allow the earth to be a perfect sphere, is necessary to have compress and cool down atmospheric vapor, so that it may precipitate as water. Marwan Rashed discussed the teleological foundation of Ibn Qurra's philosophical thought. Rashed also connected this treatise on the utility of the mountains to Ibn Qurra's treatise on "why sea water is salty" (Ar. Qawl fì Sabab alladhī Ju'ilat lahu Miyāh al-Bihar Māliha), ${ }^{28}$ where Ibn Qurra states that the reason for the presence of salt is to avoid the corruption that befalls sweet water, for instance in swamps. ${ }^{29}$ Al-Bīrūnī addressed the subject a few years later in the Tahdīd, which he wrote in Ghazna between 1018 and 1025 CE:

The salinity, according to Tābit b. Qurra, prevents the water from getting foul, and eliminates putrefaction, which would be disastrous to His intended creatures [...] [God] commanded the winds to drive water vapor, in the form of clouds, to desolate and waterless lands, so that its rain in those lands will refresh and sustain the lives of animals and plants over there, and its rain on the mountains will penetrate and accumulate deep inside them, or will remain on their tops in the form of snow. Further, the accumulated water will form rivers which will carry it back to the sea, but their courses will run by the dwelling places of peoples and animals, who will use the water for drinking and other utilities. These benefits could not have been possible, if the solute in the sea water were other than salt; because vapors of solvents, except the vapors of saline solvent, carry the taste of solutes dissolved in them. ${ }^{30}$

In a following paragraph [ $₫ 6]$ he further clarifies that, since in winter there is a steep increase in water precipitation, some of this water "seeps down into the pores and the mountain caves, and there is stored up" over the course of the cold season. The caves are the reservoirs that feed springs and are not to be confused with the cavities deep in the Earth where water is generated from condensation of the air element in the endogenous model of the water cycle. ${ }^{31}$ On the contrary, this statement further confirms that al-Bīrūnī in the Ātār adheres to an exogenous model. Moreover, he employs the model to explain in general terms the functioning of karst system, ${ }^{32}$ linking it to the teleological concept of the divine design of the creation, in which the natural world functions as a perfect engine towards its own regeneration. ${ }^{33}$ Al-Bīrūnī singles out among water springs those which fall under the category of "bubbling springs", which would seem to negate a physical principle that he seems to hold dear, that water may rise in height only if its reservoir is higher than the spring itself. In other words, al-Bīrūnī states that water may not rise higher than its reservoir, that in the case of natural occurring springs is the mountain caves. This general principle appears to have been a point of

the Banū 'Irāq (Fourth/Tenth Century)', Iran 38, no. 1 (2000): 71-75, https : //doi .org/10.2307/4300583; E. S. Kennedy and Ahmad Muruwwa, 'Bīrūn̄i on the Solar Equation', Journal of Near Eastern Studies 17, no. 2 (1 April 1958): 112-21, https://doi.org/10.1086/371451.

28 The manuscript, of which an important paragraph was translated by Rashed, is Ms. Topkapi Saray, Ahmet III 3342, fol. 195v 201v: Qawl fì Sabab alladhī Ju'ilat lahu Miyāh al-Bihar Māliha. Marwan Rashed, 'Thābit ibn Qurra, la Physique d'Aristote et le meilleur des mondes', in Thābit ibn Qurra: science and philosophy in ninth-century Baghdad, ed. Roshdi Rashed, Scientia Graeco-Arabica 4 (De Gruyter, 2009), 705-6.

${ }^{29}$ Marwan Rashed, 'Thābit ibn Qurra, la Physique d'Aristote et le meilleur des mondes', in Thābit ibn Qurra: science and philosophy in ninth-century Baghdad, ed. Roshdi Rashed, Scientia Graeco-Arabica 4 (De Gruyter, 2009), 706.

30 Al-Bīrūn̄, The Determination of the Coordinates of Positions for the Correction of Distances between Cities, trans. Jamal Ali, reprinted Frankfurt: Institute for History of Arabic-Islamic Science, 1992, Islamic Geography vol. 26, pp. 24-25 (Beirut, 1967), 24-25; Al-Bīrūn̄̄, Tahdīd Nihāyat Al-Amākin Li-Taṣhịḥ Masāāāt al-Masākin, ed. Pavel G. Bulgakov and I. Ahmad, Reprinted Frankfurt: Institute for History of Arabic-Islamic Science, 1992, Islamic Geography vol. 25, pp. 34-35. (Machad al-Mahtūtāt al-'Arabiyya, 1962), 34-35. See also a partial translation of this passage in Kish, A Source Book in Geography (Cambridge (MA); London: Harvard University Press: 1978) 216.

31 This theory is discussed in the Arabic version of Aristotle's Meteorology. Pieter L. Schoonheim, ed., Aristotle's Meteorology in the Arabico-Latin Tradition: A Critical Edition of the Texts, with Introduction and Indeces (Leiden; Boston Köln: Brill, 2000), 61-75.

${ }^{32}$ Karst systems are large geological formations due to the dissolution of soluble rocks. They are characterized by underground drainage systems with sinkholes and caves. Karst systems are distributed around the world and characterize vast areas in the Mediterranean region, in north Africa and the vast majority of Iranian Plateau, they are present as well in central Asia.

${ }^{33}$ Seyyed Hossein Nasr, An introduction to Islamic cosmological doctrines: conceptions of nature and methods used for its study by the Ikhwān al-Ṣafā, al-Bīrūnī, and Ibn Sīnā (Bath: Thames \& Hudson, 1964), 122-25. 
contention between al-Bīrūnī and some of his acquaintances. The author devotes relatively ample space [ף8 - đ9] to the objection of some anonymous contender who evidently did not accept al-Bīrūnì's thesis that water may never rise above its reservoir.

\section{The Hydraulic Jump}

Al-Bīrūnī dismissed the observation as a result of faulty measurements [ $\lceil 9$ - \10], but we should spend a few words on it. The passage lends itself to a different reading than the one al-Bīrūnī intended. It is evident here that al-Bīrūnī is dismissing an empirical observation because it is not in agreement with his theoretical principle. In agreement with his empirical approach, he cannot argue against it on a theoretical basis and is therefore brought to postulate some form of optical illusion or, worse, incompetence. Nevertheless, the physical phenomenon known today as the hydraulic jump could explain what was reported to al-Bīrūnī. According to his informers, peasants are capable of building irrigation infrastructures that force water to move slightly upwards. The phenomenon occurs in hilly or mountainous countryside a landscape like the surroundings of Ğurğān. There, al-Bīrūnī is told, peasants may deviate steep natural streams into

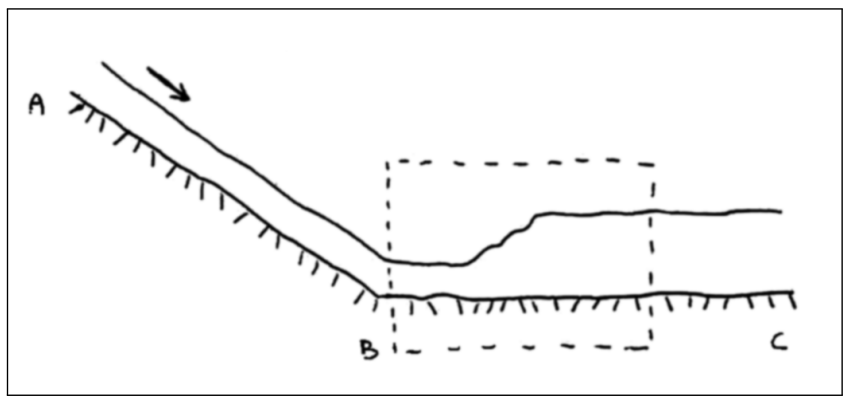

Figure 2: Hydralic Jump after a Slope

channels with little to none inclination, where the height of the water increases. ${ }^{34}$ It may well be that the anonymous observers were in fact describing what we know today as the hydraulic jump. The hydraulic jump is a phenomenon that occurs when a flow presents a transition from supercritical to subcritical flow. Sparing the physical model and the mathematics connected the phenomenon it is important to notice that a reduced height of the flow corresponds to a higher flow velocity and vice versa such that $y_{1} * v_{1}=y_{2} * v_{2}$ to ensure the same discharge before and after the hydraulic jump. ${ }^{35}$

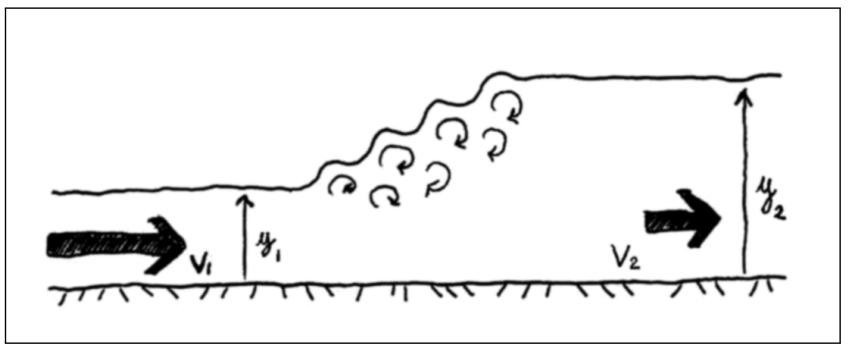

Figure 3: Hydralic Jump

\footnotetext{
${ }^{34}$ See Figure 2

35 See Figure 3.
} 


\section{Siphons and Void}

Be that as it may, al-Bīrūn̄̄ builds upon his argument on the physical behaviour of water, taking into consideration the techniques that makes it possible to raise water [ 111 ]. Here, the main concern of the author is to provide an explanation coherent with the principle that water may not rise above its point of origin, countering any possible argument against it in relation to artificial machines. He describes three examples, presented as applications of the syphon: a water-thief or clepsydra [ 12 - \13], the construction of artificial fountains [ $\mid 14]$, and the natural occurrence of high-pressure springs in Yemen [ף15]. Al-Bīrūnī explains the functioning of the water-thief with the principle of horror vacui [ $\mid 12$ - \13]. ${ }^{36}$

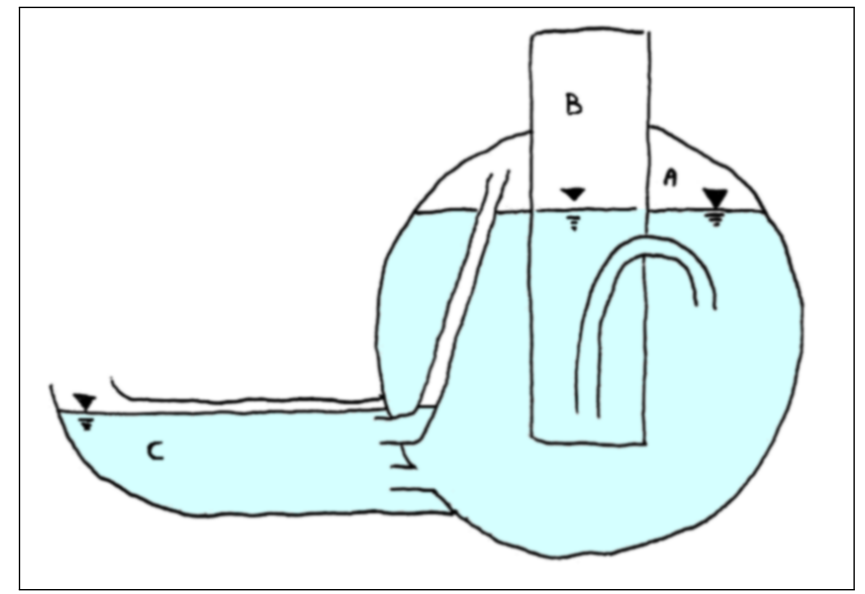

Figure 4: A Self-Feeding Lamp

The fact that void cannot be or, in alternative, pulls other bodies to fill it, is the reason why water stands in a syphon at a

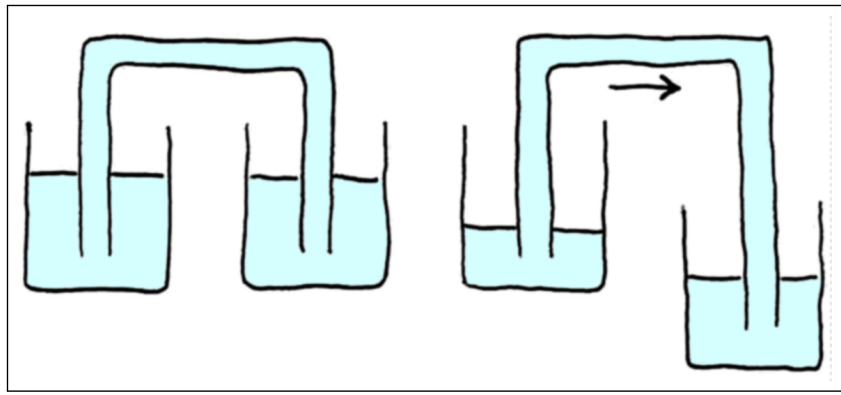

Figure 5: The Working of a Syphon

higher level than the water in the basins it connects if the water in the basins is at the same level. ${ }^{37}$ The question of whether void is possible or not was much debated at the time. Some, as Ibn Sinnā, and the Mu'tazilites from Baghdad, opposed the possibility of void. Others, such the Mu'tazilites from Basra and Abū Bakr al-Rāzī (ca. 250/854-313/925 or 323/935), maintained that void is indeed possible and attracts other bodies. Paul Hullmeine convincingly argued in a recent article that al-Bīrūn̄̄'s position on the matter was characterized by a possibilist agnosticism, both in in this passage and in later passages, and that he was "at minimum [...] not satisfied by the arguments that have been set forth against void's existence". ${ }^{38}$ In the second example [ |14], al-Bīrūnī describes the functioning of artificial fountains built

${ }^{36}$ See Figure 4

${ }^{37}$ See Figure 5

38 Paul Hullmeine, 'Al-Bīrūnī and Avicenna on the Existence of Void and the Plurality of Worlds', Oriens 47, no. 1-2 (13 May 2019): 3-6, 11, https : //doi .org/10.1163/18778372-04701002. 
from natural occurring water wells. He differentiates between two kinds of water wells, known today as phreatic and artesian wells. According to al-Bīrūnī, an artificial fountain can gain enough pressure only if its water comes bubbling from the bottom of the well, excluding wells that receive water from surrounding aquifers. This explanation is perfectly coherent with the author's general principle of communicating vessels. Natural wells receiving "bubbling water" or artesian sources are fed by a higher reservoir, which sets the upward limits of the water's rise. For the third example [ $\llbracket 15]$, al-Bīrūnī relies on an anonymous oral source on Yemeni water discovery traditional practices. His source states that some water springs may have built up enough pressure to trigger wide scale floods such as the sixth century (ca. 532 CE) Sayl al- 'Arīm that destroyed the Marīb oasis. ${ }^{39}$ After having discussed in depth the general principle, al-Bīrūnī mentions a few ' $a \grave{g} \bar{a} ’ i b$, natural or man-made counterintuitive phenomena [ $₫ 16$ - $\mid 24]$. For some of them, he provides sources and some explanation, for others, we are left in the dark. The first case cited by al-Bīrūnī is the lake of Sabzarūd [ $₫ 16-\llbracket 18]$, which is also the most relevant one to understand al-Bīrūn̄̄s view of hydraulics at this early stage in his career. Sabzarūd lake is a small pond of water known today as Chashmeh Su. The fact that the old and new names describe its green colour, "green lake" and "green light" respectively, seems to confirm that. Al-Bīrūnī does not say why he chose this lake as an example, but it has probably to do with the fame of Sabzarūd since Pre-Islamic times. Fatemeh Jahanpur has argued that there was a temple by its shores. ${ }^{40}$ According to a report by Ibn Balhī, a white horse emerged from its green waters to trample the unjust ruler Yazdagird $\mathrm{I}^{41}{ }^{4}$ The lake was therefore well known, which should explain al-Bīrūn̄̄'s interest in this pond. The actual origin of Sabzarūd's waters may simply be seasonal snowfall, but al-Bīrūnī never considers this possibility. ${ }^{42}$ Instead, he seems certain that it must be fed by some distant

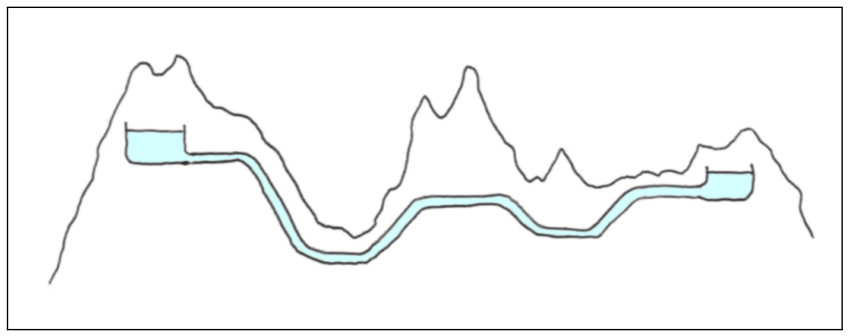

Figure 6: Hypothetical Underground Syphon

reservoir, located on a higher mountain. All three explanations provided by the author rely on the same principle of the communicating vessels. ${ }^{43}$ In one case the reservoir is higher than the green lake [ $\left.₫ 16\right]$, in another it is on the same level [ף16], and in the third a more complex natural mechanics is at work [ף18]. Al-Bīrūnī compares it to a machine or instrument called al-dah̆̆, of which we have found no other mentions. Fortunately for us, al-Bīrūnī explains with some detail its functioning ${ }^{44}$ and says it is quite like the self-feeding lamp, of which we have descriptions in other technical works, such as the Book of Ingenious Devices by Mūsā b. Šākir. ${ }^{45}$ It is not clear how this model would translate into

39 Sayl al-'Arīm, literally "the flood of 'Arīm", probably from Sabian 'rm meaning dam. The expressions al-sayl al-'arim and sayl 'arim came to mean any highly violent flood. W. W. Müller, "Mārib", Encyclopaedia of Islam, Second Edition, 24 April 2012, https://referenceworks.brillonline.com/entries/encyclopaedia-of-islam-2/marib-SIM_4964; Ingrid Hehmeyer, 'A History of Water Engineering and Management in Yemen: Material Remains and Textual Foundations', Handbook of Oriental Studies: Section 1, the Near and Middle East 129 (Leiden; Boston: Brill, 2019), 23-24, 48-56, https://brill.com/view/title/39434.

${ }^{40}$ Fatemeh Jahanpur, 'Ta'ammoli Dar Nām-e Chashmeh Su', Faslnāmeh Tārikh-e Iran Bāstān 3 (2006/1385):1-16, 12. On this lake and its legends see also Davoud Monchi-Zadeh, Topographisch-historische Studien zum Iranischen Nationalepos, vol. 2, Abhandlungen für die Kunde des Morgenlandes 41 (Wiesbaden: Deustche Morgenländische Gesellschaft, 1975), $201-203$.

${ }^{41}$ Parvaneh Pourshariati, Decline and Fall of the Sasanian Empire: The Sasanian-Parthian Confederacy and the Arab Conquest of Iran (London: I. B. Tauris, 2008), 66-67.

42 This is curious, since snowmelt was one the sources of water for small lakes on mountaintops theorized by al-Karajī, and it may suggest that al-Bīrūnī was not aware of his work at time. Niazi, 'Karajī’s Discourse on Hydrology', 64.

43 See Figure 6.

44 See Figure 7.

45 Donald R. Hill, The Book of Ingenious Devices by the Banū (Sons of) Mūsa Bin Shākir (Dordrecht: D. Reidel Publishing Company, 1979), 232. 


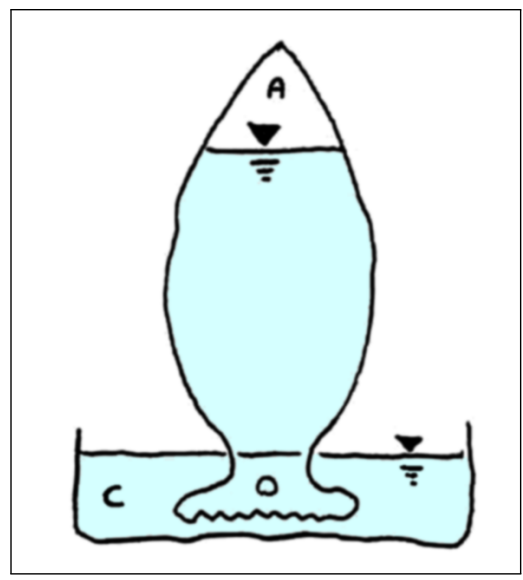

Figure 7: Al-Dahğ

the physical reality of a mountain lake, but our best guess is that al-Bīrūnī envisions here a wider closed reservoir in the peaks around the Sabzarūd, which lies in a small valley closed on all sides by mountain peaks. These reservoirs would be connected to the lake by both a submerged water spring and an opening at water level, which would act as a regulation system, allowing the inflow of water as the lake naturally dries up, and preventing it to flow when the level of the lake surpasses its closing the only source of air to the reservoir. Al-Bīrūnī mentions two more lakes that, to his knowledge and probably from his reading of geographical literature, lie on top of their respective mountain without any evident reservoir higher than themselves. The first one is a very small lake near a mountain called Mankūr, in the country of the Kimek (ar. Kìmāk) [ף19]. The Kimek lead a Turkish confederation located between the Ob and Irtysh rivers, and the identification of said mountain is debated. Marquart proposed in the thirties a restoration of Mankūr in min kol, meaning "thousand lakes", ${ }^{46}$ while Minorsky advocated an identification with a mountain mentioned in the

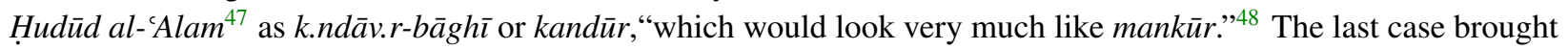
up by al-Bīrūnī, a small lake on the mountains of Bāmiyān, could not be identified. From this point onwards, the author leaves aside any scientific inquiry and the digression becomes a mere presentation of marvellous and strange phenomena. In some cases, not even related to water, as is the case of the last anecdote retold by al-Bīrūni on the self-moving column in Alexandria. The purpose of these factoids is probably to give the reader a chance to rest from the more technical discussion of the digression, before returning to the structure of the Rum $\bar{\imath}$ calendar, which is the main subject of the chapter.

\section{Conclusions}

In conclusion, the main preoccupation of al-Bīrūnī in the brief digression translated and analysed in the present paper was to elaborate on the general principle that water may not rise above its point of origin. For us, this passage is first and foremost a significant example of how al-Bīrūni conceived the water cycle, at least at the time of his employment at the Ziayrid court. While it is true that al-Bīrūnī does not state openly in these pages a belief in the exogenous cycle, it is abundantly clear that he thought of the natural water cycle as a closed system for both scientific and teleological reasons. Al-Bīrūnī presents the reader with a counterargument to his central statement that he proceeds to refute. The case of the uprising channel is not discussed at length, but it is nonetheless noteworthy. Based on al-Bīrūnì's description of the phenomenon, it could be hypothesized that his anonymous source, or contender, witnessed a hydraulic jump being exploited for irrigation purposes.

46 J. Marquart and W. Bang, 'Uber das Volkstum der Komanen', Osttürkische Dialektstudien 13, no. 1 (1914): $25-238$.

47 Anonymous, Hudud Al-'Alam 'The Regions of the World': A Persian Geography 372 A.H.-982 A.D, trans. Vladimir Minorsky and Vasilij Vladimirovič Bartol'd (London: Messrs Luzac \& Co., 1937), 66.

${ }^{48}$ Minorsky and Bartol'd, 202; V. Minorsky, 'The Khazars and the Turks in the Ākām Al-Marjān', Bulletin of the School of Oriental Studies, University of London 9, no. 1 (1937): 141-50. 


\section{Translation}

Borroni and Boselli's Translation
[ 1 1]On the 28th [of Nīsān] there is wind according to the Copts,
and rain according to Eudoxus. Sinan confirms the rain from
his own observations. It is said that the south wind blows on
this day, and that the streams and rivers begin to grow. This
increase of the water does not happen in all streams and rivers
in the same way. On the contrary, they differ a great deal from
each other in this respect.

[ 92$]$ For instance, the Oxus has high water when there is little water in the Tigris, Euphrates, and other rivers. This happens because [rivers] that originate from streams in colder places have more water in summer and less in winter. The reason for this is that the greatest part of their originary waters is gathered from springs. Now, their growth or shrinking depends on the amount of precipitation in those mountains from which the rivers come or through which they pass, so that their flows pour into the rivers.

[93]It is no secret that there is more precipitation in winter and beginning of spring than in any other season, and that it freezes during those seasons in the northernmost countries, where the cold is intense. [Therefore,] it is when the air gets warm and the snow melts, that the Oxus rises. As for the water of the Tigris and Euphrates, their sources are less high up in the north. Therefore, the growth of these two happens in winter and spring, because the precipitation flows into the rivers just as soon as it falls. Moreover, the portion that may have been frozen melts away in the beginning of spring.

[ฯ4]As for the Nile, it grows when Tigris and Euphrates shrink This is because its source lies in the Mons Lunae, as it has been said, beyond Assuan - the city the Abyssians in the southern region - either at the Equator, or beyond it. This is, however, a matter of doubt, because those surroundings are not inhabited, as we said earlier. It is evident that in those regions any freezing of moist substances is impossible. Therefore, it could either be that the growth of the Nile is caused by precipitated water, as it is evident that the water does not stay where it has fallen, but flows off to the Nile at once, or that it is caused by the springs, that have the most water in winter. [In the latter case,] the Nile rises in summer, because when the sun is near us and at our zenith, it is far away from the zenith of those regions whence the Nile originates, and it is winter there.

\section{Sachau's Translation}

[ $\mid 1]$ Wind (Egyptians); rain (Eudoxus). Sinan confirms the rain from his own observations. On this, they say, the south wind blows, and then the streams and rivers begin to rise. This increase of the water, however, does not apply to all streams and rivers uniformly; on the contrary, they greatly differ from each other in this respect.

[ๆ2]E.g. the Oxus has high water when there is little water in the Tigris, Euphrates, and other rivers. The fact is this, that those rivers the sources of which are situated in cold places, have more water in summer and less in winter. For the greatest part of the ordinary volume of their water is gathered from springs, and an increase and decrease of them exclusively depend upon the fall of dew in those mountains where the rivers originate or through which they flow; thereupon the springs pour their volumes into the rivers.

[ $₫ 3]$ Now it is well known that dew-fall is more frequent in winter and beginning of spring than at any other season. In the countries far up to the north, where the cold is intense, this dew-water freezes at those seasons. But when the air is getting warm and the snow melts, at that time the Oxus rises. As for the water of the Tigris and Euphrates, their sources are not so high up in the north. Therefore they have high water in winter and spring, because the dew that falls flows instantaneously into the rivers, and that portion of water that may have been frozen melts away in the beginning of spring.

$[\llbracket 4]$ The Nile, again, has high water when there is low water in both Tigris and Euphrates, because its source lies in the Mons Lunae, as has been said, beyond the Abyssinian city Assuan in the southern region, coming either exactly from the equator or from countries south of the equator. This is, however, a matter of doubt, because the equatorial zone is not inhabited, as we have before mentioned. It is evident that in those regions there is no freezing of moist substances at all. If, therefore, the high water of the Nile is caused by falling dew, it is evident that the dew does not stay where it has fallen, but that it directly flows off to the Nile. But if the high water is caused by the springs, these have the most abundant water in spring. Therefore, the Nile has high water in summer, for when the sun is near us and our zenith, it is far distant from the zenith of those places whence the Nile originates, and which in consequence have winter. 


\section{Borroni and Boselli's Translation}

[95]Regarding the question why the water of springs is most copious in winter, it is because the all-wise and all-mighty Creator intended to place the mountains [on earth] for a number of beneficial uses, some of them mentioned by Tābit b. Qurra in his book on why the mountains were created. This reason [that interests as here] is to fulfil [his] intention of making the water of the seas salty.

[96]Clearly, precipitation in winter is higher than in summer, and they are higher in the mountains than in the plains. When [this water] falls, a part of it flows away in the torrents and the remaining part seeps down into the pores in the mountain caves, and there it is stored up. Afterwards, it begins to come out from the holes that are called springs. That is the reason why [this water] is most copious in winter: it is because there is more of its own substance. Moreover, if these mountain caves are clean and pure, the water flows out just as it is, agreeable [to the taste]. If that is not the case, the water acquires different qualities and peculiarities, the causes of which are hidden from us.

[ๆ7]With regards to the bubbling of the springs and the upward rising of the water, they are due to the fact that their reservoirs lie higher than [the springs] themselves, as is the case with artificial well-springs, for water may rise in height for this reason only.

[98]Many who just say "God knows best" when confronted with what they ignore of natural sciences have argued with me on this subject. In support of their conviction, they relate that they have observed the water rise in rivers and watercourses, and that the water was rising as it flowed away. They assert this only because of their ignorance of the physical causes and their inaccuracy in distinguishing between what is higher and what is lower.

[ 99$]$ The fact is that they observed running water in the middle of mountain streams, which go downward at the rate of 50-100 cubits and more per one earth mile of distance. ${ }^{49}$ If, somewhere along its course, the peasants dig a small channel, and this channel is built with just a gentle inclination, the water [at first] flows just a little, until it rises to a height that exceeds that of the water of the stream [from which it departed].

\section{Sachau's Translation}

$[\llbracket 5]$ As to the question why the springs have the most copious water in winter, we must observe: the all-wise and almighty Creator, in creating the mountains, destined them for various purposes and uses. Some of them have been mentioned by Thābit b. Kurra in his book on the reason why the mountains were created. It is the same cause which renders complete the intention (of the Creator) which he had in making the sea-water salt.

[ $₫ 6]$ Evidently more wet falls in winter than in summer, in the mountains more than in the plains. When, now, the wet falls and part of it flows away in the torrents, the remaining part sits down into the channels in the mountain caves, and there it is stored up. Afterwards it begins to flow out through the holes, called springs. Therefore, the springs have the most copious water in winter, because the substance by which they are nourished is then most copious. If, further, these mountain caves are clean and pure, the water flows out just as it is, i.e. sweet. If that is not the case, the water acquires different qualities and peculiarities, the causes of which are not known to us.

[97]The bubbling of the fountains and the rising of the water to a certain height are to be explained in this way, that their reservoirs lie higher than they themselves, as is the case with artificial well-springs, for this is the only reason why water rises upward.

[ 98$]$ Many people who attribute to Grod's wisdom all they do not know of physical sciences (i.e. who excuse their ignorance by saying "Allah is all-wise".), have argued with me on this subject. In support of their view they relate that they have observed the water rise in rivers and other watercourses, that the water the more it flows away (from its source) the more it rises. This they assert in complete ignorance of the physical causes and because they do not sufficiently distinguish between the higher and lower situations (of the springs of rivers and of the rivers themselves).

[ 99$]$ The matter is this, that they observed water flowing in mountain streamlets, the bed of which was going downward at the rate of 50-100 yards and more for the distance of one mile. If the peasants dig a channel somewhere in this terrain, and this channel is made to incline a little towards the country (i.e. if the channel is rising), at first the water flows only very little, until it rises to an enormous height above the water of the river; (then it commences to flow strongly).

49 One $m \bar{l} l$ equals 4000 dira $^{c}$ Walter Hinz, "Farsakh", in Encyclopadia of Islam, Second Edition, 2012, http://dx.doi.org/10.1163/1573-3912_islam_SIM_2299. 


\begin{abstract}
Borroni and Boselli's Translation
[ 10$]$ If someone who has no training believes that course of the wadi is horizontal or with a small inclination, he will imagine that it is necessary that the small channel is rising in height, and it is impossible to free their mind from this illusion unless they acquire experience with the instruments by which the land is measured, and by which rivers are dug and excavated. When they measure the land where the water is flowing, something different from what they believed becomes clear to them. In alternative, they need to study physical sciences and know that the motion of water proceeds towards the centre [of the earth,] and to any point that is nearest to it.
\end{abstract}

[ 111$]$ Of course, water may rise as much as it is wanted to, even to the tops of the mountains, when its point of [final] descent is lower than its point of [initial] ascent and anything that might occupy its place when the water vacates it is prevented from doing so. [Since] the water flows naturally only thanks to the co-operation of [something] that forces it, which [in the present case] is the air. This has been done often in rivers on whose path there were mountains which were impossible to cut.

[ 12$]$ An illustration of this principle is the instrument called Water-thief. If you fill it with water and put both its ends into two vessels, in both of which the water reaches to the same level, then the water in the Water-thief stands still even for a long time, not flowing off into either of the two vessels, because both vessels are equally close [to the center of the earth,] and it would be impossible for the water to flow off equally into both vessels, for in that case the instrument would void itself and the void is either a non-ens, as some philosophers suppose, or it is an ens which attracts bodies, as others believe. If the existence of [the void] is impossible, it will not be there, and if it is something which attracts bodies, it will hold water back, not letting it flow off, except in case its place is occupied by some other body.

[ 913$] \mathrm{But}$ if one end of the Water-Thief is moved a little lower (than the other), then what is inside the [higher] vessel flows off towards it. This happens because, since it has been lowered, it has come nearer to the centre of the earth, and so [the water] flows towards it, and the flux becomes continuous in consequence of the adhesion and connection of the atoms of water amongst each other. [The flow] continues until the water of that [higher] vessel, whence the water is drawn, is finished, or until the level of the water in the [lower] vessel where it flows is equal to the level of the water in the [higher] vessel whence it is drawn, when the question is in original state once again. On the mountains, [people] have proceeded in a similar way.
Sachau's Translation

[ $\ 10]$ If, now, a man who has no training in these things believes that the natural direction of the river is to flow in a horizontal line or with a small inclination (upwards), he must of necessity imagine that the river is rising in height. It is impossible to free their mind from this illusion unless they acquaint themselves with the instruments by which pieces of soil are weighed and determined, and by which rivers are dug and excavated - for if they weigh the earth through which the water flows, the reverse of what they believe becomes evident to them ; - or unless they study physical sciences, and learn that the water moves towards the centre of the earth and to any place which is nearest to the centre.

[911]There is no doubt that the water may rise to any place where you want to have it, even if it were to the tops of the mountains, if previously it descends to a place which is lower than its maximum of ascent (which it ultimately reaches), and if you keep away from it any substance which might occupy the place instead of the water when it finds the place empty. Now, the water in its natural function is only assisted by the cooperation of something forcible which acts like an instrument, and that is the air. This has frequently been carried out in canals, in the midst of which there were mountains which it was impossible to perforate.

[ 912$]$ An illustration of this principle is the instrument called Water-thief, $\kappa \lambda \varepsilon \psi \nu \delta \rho \alpha$. For if you fill it with water and put both its ends into two vessels, in both of which the water reaches to the same level, then the water in the $\kappa \lambda \varepsilon \psi \nu \delta \rho \alpha$ stands still even for a long time, not flowing off into either of the two vessels. For the one vessel is not nearer (to the water) than the other, and it is impossible that the water should flow off equally into both vessels, for in that case the instrument would get empty. Now, emptiness is either a non-ens, as most philosophers suppose, or it is an ens which attracts bodies, as others believe. If, now, the vacuum cannot exist, the matter is impossible, or if it is something which attracts bodies, it keeps back the water and does not let it flow off, except its place be occupied by some other body.

[ $\mid 13] \mathrm{But}$ if you then place the one end of the $\kappa \lambda \varepsilon \psi \nu \delta \rho \alpha$ a little lower (than the other), the water 20 flows immediately off into that direction. For if its place has once become lower, it has come nearer to the centre of the earth, and so it flows towards it, flowing continually in consequence of the adhesion and connection of the water-atoms amongst each other. It flows so long until the water of that vessel, whence the water is drawn, is finished, or until the level of the water in the vessel where it flows is equal to the level of the water in the vessel whence it is drawn. So the question returns to its original condition. On this principle people have proceeded in the mountains. 


\begin{tabular}{l} 
Borroni and Boselli's Translation \\
\hline [ 14 ]It is quite true that the water rises in artificial fountains out \\
of wells, in case they have bubbling water. [On the contrary,] \\
there is a sort of well-water, which is gathered from droppings \\
from the sides, that does not rise at all. [This latter kind] is \\
acquired from waters that are nearby, and the level of the water \\
which is gathered in this way is parallel to the level of those \\
waters by which it is fed. But there is one kind of water which \\
bubbles at the bottom of the well. It is desirable and possible \\
that this water people springs from beneath the earth, flowing \\
on over above ground. This latter kind of water is mostly found \\
in countries near to mountains with no lakes or deep rivers. If \\
the source of such water is a reservoir above the level of the \\
earth, the water rises bursting, if it is confined (through a small \\
pipe). but if its reservoir is lower, the water does not reach \\
the level of the earth and it does not burst out. Frequently the \\
reservoir is higher by thousands of cubits in the mountains; in \\
that case the water may rise up, for instance, to the fortresses \\
or to the tops of the minarets. \\
\hline
\end{tabular}

[ 915$]$ I heard that people in Yemen at times dig until they come to a rock under which they know that there is water. Then they knock upon this rock, and by its sound they ascertain the quantity of the water. Then they bore a small hole and examine it, if it is safe, they let the water bubble out and flow where it likes. But if they have some fear about the hole, they hasten to stop it up with gypsum and quicklime and to close it over repeatedly. They do so because sometimes they fear that from such a hole a spring like the Flood of 'Arim might originate.

[ 16$]$ As to the water on the top of the mountain between Abarshahr and Tūs - a small lake of one farsang in circumference, called Sabzarūd - there is no doubt that its case is as follows: Either it comes from a reservoir higher than the lake itself, although it may be far distant. The water flows into it in such a quantity as corresponds to that which the sun dries up and evaporates. At which point, the water of the lake stands still in the same state.

$[\Upsilon 17]$ Or its material is derived from a reservoir which lies on the same level with the lake, and therefore the water of the lake does not rise above that of the reservoir.

\section{Sachau's Translation}

[ 914$]$ Sometimes even the water rises in artificial fountains out of wells, in case they have got springing water. For one sort of well-water, which is gathered from droppings from the sides, does not rise at all ; it is taken from neighbouring masses of water, and the level of the water which is gathered in this way is parallel to the level of those waters by which it is nourished. On the other hand there is one kind of water which bubbles (springs) already at the bottom. Of this water people hope that it may rise to the earth and flow on over its surface. This latter kind of water is mostly found in countries near to mountains, in the midst of which there are no lakes or rivers with deep water. If the source of such water is a reservoir much above the level of the earth, the water rises springing, if it is confined (to a narrow bed or channel) ; but if its reservoir be lower, the water does not succeed in rising to the earth. Frequently the reservoir is higher by thousands of yards in the mountains; in that case the water may rise up to the castles, and, e.g., to the tops of the minarets.

[ $\mid 15]$ I have been told that people in Yaman often dig until they come to a certain rock under which they know that there is water. Then they knock upon this rock, and by the sound of the knocking they ascertain the quantity of the water. Then they bore a small hole and examine it ; if it is all right, they let the water bubble out and flow where it likes. But if they have some fear about the hole, they hasten to stop it up with gypsum and quicklime and to close it over repeatedly. For frequently they fear that from such a hole a spring similar to the Torrent of AVarim might originate.

[ 16$]$ As to the water on the top of the mountain between Abrashahr and Tus, a small lake of one farsang in circumference, called Sabzarod, one of the following three things must be the case : 1. Either its material is derived from a reservoir much higher than the lake itself, although it may be far distant, and the water flows into it in such a quantity as corresponds to that which the sun absorbs and vaporises. Therefore the water of the lake remains in the same condition, quietly standing.

[ $₫ 17]$ Or its material is derived from a reservoir which lies on the same level with the lake, and therefore the water of the lake does not rise above that of the reservoir. 


\section{Borroni and Boselli's Translation}

[ 18 ] Or the deal with its sources is like that of the water of the instrument called al-Dahj, and the self-feeding lamp. The [general] idea is this: You take a jar for water, or an oil-vase; in several places of the edge of the vase [or of the jar] you make fine splits, and you make a narrow hole lower than the mouth by so much as you wish the water to remain in the basin [where you will place the jar] or the oil in the lamp [where you intend to place the oil-vase]. Then, you fill [the jar or the oil vase] up and you turn the jar upside down in the basin or the oil-vase in the lamp. Then the water or the oil will flow out through the fine splits, until they reach the level of the [narrow] hole. When [the oil or water] just under the level the hole is consumed [so that the level of the fluid decreases under the hole], then, [the oil or water] which lies in the proximity of the hole flows off [to the lamp or the basin, through the fine splits]. In this way both oil and water keep the same level.

[ 19$]$ Similar to this little lake, there is a sweet water spring in the country of the Kīmāk on a mountain called Mankūr, as large as a great shield. The surface of its water is at the same level of its margins. Sometimes, an army drinks out of this spring, and still it does not decrease by a finger. Near this spring there is a rock with the traces of the foot, two hands with the fingers, and two knees of a man who had been worshipping there; also, the traces of the foot of a child, and of the hoofs of an ass. The Ghuzz Turks worship them when they see them.

[ 120$]$ There is another small lake, similar to those, in the mountains of Bāmiyān, one-mile square, on the mountain top. The water of the village which lies on the slope of the mountain comes down through a small hole, enough for their needs, but they are not able to make it larger.

\section{Sachau's Translation}

[ 18$]$ Or, lastly, the condition of its sources in some way resembles that of the water of the instrument called Al-dahj, and the self-feeding lamp. The case is this: You take a water-jug, or an oil-vase ; in several places of the edge or lip of the vase you make fine splits, and you bore a narrow hole in it deeper than the mouth by so much as you wish the water to remain in the jug and the oil in the vase (i.e. the hole is to represent the line to which people wish the water or oil to rise). Thereupon you turn the jug upside down in the cup and the vase in the lamp. Then both water and oil flow out through the splits, until they reach the level of the hole. When, then, so much has been consumed as the hole allows to pass, then comes forth that which lies next to the hole. In this way both oil and water keep the same level.

[ 119$]$ Similar to this little lake is a sweet-water well in the district of the Kimak in a mountain called Mankur, as large as a great shield. The surface of its water is always on a level with its margin. Frequently a whole army drinks out of this well, and still it does not decrease as much as the breadth of a finger. Close to this well there are the traces of the foot, two hands with the fingers, and two knees of a man who had been worshipping there; also the traces of the foot of a child, and of the hoofs of an ass. The Ghuzzi Turks worship those traces when they see them.

[ $\$ 20]$ Moreover, similar to this is a small lake in the mountains of Bamyan, one mile square, on the top of the mountain. The water of the village which lies on the slope of the mountain comes down from that lake through a small hole in such a quantity as they require; but they are not able to make it flow more copiously. 


\section{Borroni and Boselli’s Translation}

[ $\mid 21]$ Sometimes, the bubbling occurs also in a plain country which gets [its water] from a high reservoir. The bubbling gets high if there is nothing that prevents it, and when any obstacle is removed, as has been the case in the village between Bukhara and al-Qāriya al-Hadītha, mentioned by al-Jayhānī, where there is a hill where people who were searching for hoard and hidden treasures went digging. At some point they found water, and were unable to contain it, so that it has been flowing ever since till this day.

[ 122$]$ If you are impressed [by these phenomena], you will be as well for the place called Fīlawān, in the neighborhood of al-Mihrağān. This place is like a ledge dug out in the mountain, from the roof of which water is always percolating. When the air gets cold, the water freezes over it in long icicles. I have heard the people of al-Mihrağann claim that they hit the place with pickaxes, and that the spot which they hit became dry, while the [output of] water never increased, even though one would rationally think that it should at least remain the same, if it does not increase.

[ |23]What al-Jayhānī relates in his Kitāb al-mamālik wa almasālik of the two columns in the grand mosque of Qayrawān, made of an unknown material, is even more wonderful. People claim that they sweat water on every Friday before sunrise. What is marvelous about it is this takes place only on Friday. If they said it may freely occur on any of the week, it could depend from the moon's reaching a certain place of the sun's orbit, or some similar reason. This, however, is not the case, since it must be Friday [for this phenomenon to occur.] They say that the Byzantine king offered to buy them. He said: "The Muslims would benefit more from their payment than from two stones in the mosque." But the people of Qayrawān refused the offer, saying: "We shall not bring them out from the house of God into that of the devil."

$[\Upsilon 24]$ The self-moving column which is in Alexandria is even more impressing than this: It inclines towards one of its sides. People put something underneath when it inclines, and when it gets upright again it cannot be taken away. When glass is put underneath, the sound of its breaking and crushing can be heard. This is no doubt that something has been manufactured, as also the place [where the column stands] points to that. Now we return to our original subject.

\section{Sachau's Translation}

[ $\mid 21]$ Frequently the springing (rising of water) occurs also in a plain country which gets its water from a reservoir in a high situation. If the rising power of the water were kept down by an obstacle, and then this obstacle is removed, the water begins at once to spring (rise). E.g. Aljaihani has mentioned a village between Bukhara and Alkarya Alhaditha, where there is a hill that was perforated by diggers for hidden treasures. Suddenly they hit upon water which they were unable to keep back, and it has been flowing ever since till this day.

If you are inclined to wonder, you may well wonder at a place called Filawan (Failawan) in the neighbourhood of Almihrjan. This place is like a portico dug out in the mountain, from the roof of which water is always dropping. If the air gets cold, the water freezes and hangs down in long icicles. I have heard the people of Almihrjan maintain that they frequently knock the place with pickaxes, and that in consequence the spot which they knock becomes dry ; but the water never increased, whilst reason would demand that it should always remain in the same condition if it does not increase.

[ 923$]$ More wonderful even than this is what Aljaihani relates in his Kitab almamalik wa almasalik of the two columns in the grand mosque of Kairawan, the material of which people do not know. People maintain that on every Friday before sunrise they drop water. It is curious that this should take place just on a Friday. If it occurred on any week-day in general, it would be combined with the moon's reaching such and such a place of the sun's orbit, or with the like of it. This, however, is not admissible, since Friday is a conditio sine qua nan of this occurrence. The Greek king is said to have sent to buy them. He said: "It is better for the Muslims to utilize their prize than to have two stones in the mosque." But the people of Kairawan refused, saying: "We shall not let them pass out of the house of God into that of the devil."

[ $\mid 24]$ Still more marvellous than this is the self-moving column in Alkairawan. For it inclines towards one side. People put something underneath when it inclines, and this you can no longer take away if the column again stands erect; if glass is put underneath, you hear the sound of breaking and crushing. This is no doubt a got-up piece of artifice, as also the place where the column stands seems to indicate. 


\section{How to Cite}

This is an authorized preprint, the paper has already passed a peer-review process and it has been accepted to be published in Arabic Sciences and Philosophy in the Issue 2 in September 2021. Please mind to cite it properly and to check the journal's website for updates.

Borroni, Massimiliano and Boselli Vladimiro. "Hydraulics and Hydrology in a Passage of the Kitāb al-Ātār al-Bāqiya by al-Bīrūnī." Arabic sciences and philosophy 31.2 (2021): ppp-qqq.

Borroni, M., Boselli, V. (2021). Hydraulics and Hydrology in a PasAPA sage of the Kitāb al-Ātāar al-Bāqiya by al-Bīrūn̄̄. Arabic sciences and philosophy, 31(2), ppp-qqq.

BORRONI, Massimiliano; BOSELLI, Vladimiro. Hydraulics and Hy-

ISO 690 drology in a Passage of the Kitāb al-Ātār al-Bāqiya by al-Bīrūn̄i. Arabic sciences and philosophy, 2021, 31.2: ppp-qqq.

Feel free to write to the authors for any questions or suggestions.

Other works from the same authors: Bridging Mediterranean cultures in the International Year of Soils 2015: a documentary exhibition on irrigation techniques in water scarcity conditions

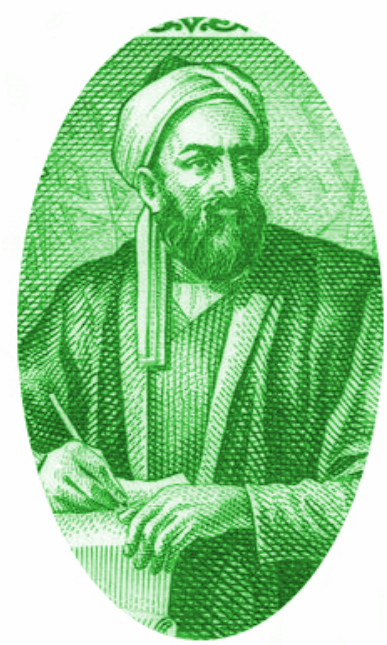

